Renia Lopez-Ozieblo*

\title{
A multimodal cognitive approach to aid the conceptualization of Spanish utterances with 'se'
}

\author{
https://doi.org/10.1515/cog-2019-0089
}

\begin{abstract}
Most native speakers of Spanish are intuitively able to construct correct structures with the marker 'se'. On the other hand, non-native speakers, even those at advanced proficiency levels, have difficulties producing most constructions with 'se'. This is hardly surprising as the marker 'se', one of the most common words in Spanish, can convey highly pragmatic nuances with a variety of functions that are still much debated among linguists. This study analyses some of the most used functions of the marker in the oral production of 18 Peninsular Spanish speakers from a multimodal Cognitive Grammar approach, identifying how gestures might be employed by speakers to create or clarify meaning. Our results confirm that gestures are used differently depending on the function of the marker. Middle voices where 'se' marks high levels of subject involvement and/or energy co-occur with related gestures, while middle voices or impersonal structures, where the involvement and/or energy is low, co-occur more often with unrelated gestures, if any.
\end{abstract}

Keywords: se, gesture, cognitive grammar

\section{Introduction}

The Spanish marker 'se' has been ascribed over 12 semantic functions (Montes Giraldo 2003), not always conforming to a homogeneous set of grammatical rules (Azpiazu Torres 2004). This makes 'se' one of the most difficult particles for grammarians to explain (Mendikoetxea 1999) and for teachers and learners of Spanish as a foreign language (ELE) to master (Peris 2006). There is ambiguous linguistic treatment of 'se' in both textbooks (Cheikh-Khamis 2018) and dictionaries (Renau 2015). Even within theoretical linguistics, the categorization of 'se'

\footnotetext{
*Corresponding author: Renia Lopez-Ozieblo, The Department of English, The Hong Kong Polytechnic University, Kowloon, Hong Kong, China, E-mail: Renia.lopez@polyu.edu.hk. https:// orcid.org/0000-0003-1752-9392
} 
structures varies from author to author, depending on their framework, resulting in varying numbers of functions and labels (Burgos nd).

This qualitative study analysed 'se' utterances produced during the narrations of 18 Peninsular Spanish speakers. The functional categorization of 'se' followed a Cognitive Grammar (CG) approach by Maldonado (1999, 2000, 2019) dividing the marked utterances as impersonal middle voices and reciprocal (there were no purely reflexive or passive sentences in the corpus). All speakers narrated the same event, an extract from a Tweety and Sylvester cartoon, enabling us to compare similar content as produced by different speakers. The main objective was to identify if and how native speakers differentiate between the various meanings of the marker 'se' with their hand gestures. Our study contributes to the field by showing how the gestures of this group of participants externalize their conceptualization of 'se', and so its function, through their gestures. Understanding this relationship will aid the teaching of the various functions of 'se' in the acquisition of Spanish as a foreign language.

The next section provides a brief summary of the various functions of 'se' from a CG perspective and is followed by an explanation of gestures. The methodology (Section 4) provides examples of how gestures were classified for the purposes of this study as well as information on corpus collection and analysis. Section 5 details and discusses the various functions of the marker 'se' observed in our corpus and the gestures co-occurring with them. Section 6 summarizes the observations and the conclusion (Section 7) suggests how they can be used in the teaching of Spanish as a second language.

\section{Cognitive grammar}

Cognitive Grammar (CG) developed as an alternative to Chomskian generative linguistics. Applied to language teaching, it seeks a functional approach where the main goal is to be able to communicate with others. In the teaching of Spanish as a foreign language (ELE), a number of pedagogues advocate this approach (Castro Castañeda 2004a; Llopis-García 2010; Maldonado 2009, 2019; Melguizo Moreno 2006; Ruiz Campillo 2007) believing that language knowledge develops through the use of language with conceptualization at its root. Such an approach presents phraseology that is neither "arbitrary nor predictable" (Bielak and Pawlak 2013: 254) through semantic and pragmatic information encoded in syntax (Langacker 1987). This means that all meanings are pragmatic and shaped by the context within which conceptualization takes place (Taylor 2003) and are therefore easier to learn for non-native language learners. 


\subsection{The marker 'se'}

CG stresses the importance of a speaker's choice when selecting the linguistic elements of an utterance: "In choosing a particular expression or construction, a speaker construes the conceived situation in a certain way" (Langacker 1987: 7). Different expressions can provide alternative views of the same scene by changing the sequence, the focus, the perspective, or the perfective aspect among other elements (Castro Castañeda 2004b). In Spanish, the marker 'se' is a commonly used resource to indicate varying conceptualizations of the same action, focussing on changes in the relationships between the participants and the action (Maldonado 1999). A number of authors have presented 'se' categorizations from a Cognitive Grammar perspective (Castro Castañeda and Moreno 2006; Araújo Júnior 2015; Torres González et al. 2018), following Maldonado's 1999 framework (developed in later publications in 2000, 2008 and 2019) resulting in an intuitive classification of the functions of 'se' centred on conceptualization.

Prior to 1970, grammars and dictionaries referred to 'se' as a reflexive pronoun after which the term 'reflexive' was replaced by 'pronominal'. Even among cognitive grammarians there exist discrepancies as to the reach of the 'reflexive' label. Maldonado (2000: 157) restricts reflexive cases with 'se' to those "where the subject and the co-referential (in)direct object can be differentiated in the event although they make reference to the same entity in the real world". The subject and the object represent different mental spaces (Fauconnier 1994), such as:

$$
\begin{aligned}
& \text { Ana se vio en el espejo } \\
& \text { Ana SE saw in the mirror } \\
& \text { 'Ana saw herself in the mirror' }
\end{aligned}
$$

In this example, we can mentally represent both the figure of Ana and the figure of her reflection in the mirror. If the subject is plural the structure with 'se' is classified as reciprocal (Castro Castañeda and Melguizo Moreno 2006). If there is "a change of state undergone by the experiencer of the event" (Maldonado 2008: 160), where the subject is the experiencer, then the reflexive is a middle voice.

The middle voice is a "system of constructions whose main property is to portray events remaining in the subject's dominion [...] depicting actions, events or changes of states" (Maldonado 2008: 155-160). The middle voice is a feature of many languages, including Hungarian, Russian, Turkish, Indonesian and classical Greek (Kemmer 1993), that distinguishes between the reflexive and the middle markers. In Spanish, the marker happens to be the same, hindering their differentiation. In middle voices (unlike reflexives), it is seldom possible to separate the two images of the subject as agent and participant. Maldonado $(2008,2009)$ proposes two 
sub-types of middle voices, both focussing on the experiencer's change of state, those resembling reflexives and those focussing on the "pivotal moment of change" (Maldonado 2009: 10). The former include self-care and self-benefit events, while the latter includes events of emotional, physical and locative changes.

A self-directed action - self-care - involves inalienable possessions, such as a part of the body or even, by extension, clothing or accessories. If the hands carry out the action (showering, brushing, putting on shoes), then 'se' is necessary and refers to the whole body to which the part receiving the action belongs (thus there is no need to use a possessive):

Beatriz se lava las manos
Beatriz SE washes the hands
'Beatriz washes her hands'

The construction of these sentences is not usually a problem for students of Spanish (except for the incorrect addition of a possessive pronoun). These relatively error-free sentences contrast with others where 'se' is optional and which are often wrongly formed by learners of Spanish, such as actions of self-benefit, consumption or change (Peris 2006). If concrete or abstract self-benefit events already imply content within the dominion of the subject/indirect object (buy, obtain, know), then the marker 'se' emphasizes the benefits.

$\begin{array}{lllll}\text { Carlos } & \text { se } & \text { consiguió } & \text { un } & \text { trabajo } \\ \text { Carlos } & \text { SE } & \text { obtained } & \text { a } & \text { job }\end{array}$

'Carlos got himself a job' (implies a pragmatic meaning of having landed a good job).

With consumption verbs (eat, drink, smoke), the marker brings the object into the dominion of the subject/indirect object which exploits it fully:

$$
\begin{aligned}
& \text { David se bebio la botella } \\
& \text { David SE drank the bottle } \\
& \text { 'David finished the bottle' (implies a pragmatic meaning of having } \\
& \text { accomplished something). }
\end{aligned}
$$

In these structures, 'se' also indicates that the object is completely affected, and that the action is short, quick or even abrupt. When metaphorical consumptions (a dance, a nap, a book) partake of the marker 'se' they also indicate a subjects' high level of involvement:

$\begin{array}{lllllll}\text { Emilio } & \text { se } & \text { leyó } & \text { el libro en dos días } \\ \text { Emilio } & \text { SE } & \text { read } & \text { the book } & \text { in two days }\end{array}$
'Emilio read the book in two days' (implies a pragmatic meaning of engagement with the book, speed and accomplishment). 
These structures are infused with an energy that differentiates them from absolute events, those depicting natural events where no energy is profiled (Langacker 1991). This energy is particularly noticeable with verbs of emotional, state or locational change. The construction of utterances expressing emotional reactions and internal emotions often requires the marker to indicate the full involvement of the agent. In the construction alegrarse 'to cheer up', the focus is on the changes undergone by the subject resulting from forces that might not be fully controlled (Maldonado 2009). These constructions differ from datives in that the experiencer "actively enacts an emotional change" (Maldonado 2009: 21) in the middle voices:

a. La música alegra a Emilio
The music cheers.up to Emilio
'The music cheers up Emilio'
b. Emilio se alegra con la música
Emilio SE cheers.up with the music
'Emilio is cheered up by the music'

In verbs of state or physical changes the middle voice compresses the energy into the pivotal moment of change (Maldonado 2009). The marker highlights the inherent semantic meaning of the verb. In the case of intransitive verbs this will be the punctual, unexpected, inchoative or termination part of the process, bringing into focus that aspect of the action (Maldonado 2000):

$$
\begin{aligned}
& \text { Francisco se fue a su casa a las seis } \\
& \text { Francisco SE went to his house at the six } \\
& \text { 'Francisco left [here] at six to go to his house' (inchoative meaning) }
\end{aligned}
$$

The middle marker can also bring out the unexpectedness of an action. It marks events that go against the known laws of nature, or predictability such as falling or suddenly dying (of something other than old age). In these cases, the marker will indicate an accidental loss of balance or a somewhat unexpected death.

In addition to the above, the marker 'se' can also indicate an impersonal or a passive construction. Although the difference between the two is not always clear (Araújo Júnior 2015), Maldonado (1999) indicates that an impersonal structure has similar elements to those of an active one but with a lower elaboration of the agent, while in a passive structure the thematic object takes the role of the subject after eliminating it. In impersonal sentences the participant, not explicitly described, gains prominence at the same time as losing responsibility. This 
participant could be someone other than the speaker or the interlocutor, either of them, or include both. The following sentence refers to an "anyone" subject:

Se ve al gato escalando la tubería
SE see to.the cat climbing the pipe
'We can see the cat climbing the pipe'

One last category, not included in our study as it was not present in the corpus, is that of passive constructions. This is the most common 'se' structure with $41.58 \%$ of all 'se' uses found in a sample extracted from the Corpus de Referencia del Español Actual (CREA) (Contemporary Spanish Corpus collected by the Spanish [Linguistics] Royal Academy) being of this form (Taibo 2011). The frequency of other uses in the CREA are: impersonal structures (13.30\%); middle voices (35\%); reflexives (3.88\%, these include self-care structures); and reciprocals (0.32\%) (Taibo 2011: 142).

\section{Gesture}

Knowledge is externalized but also created through gestures, thus making gestures 'cognitive actions' (Streeck 2009: 171). There is a conceptualization relationship between gestures and syntax (Gullberg 2011) with "grammatical notions reflect [ing] cognitive representations that are spatial in character" (Kok and Cienki 2016: 69). Thus, through analysing the structure of gestures, it should not only be possible to gain a better understanding of the syntax but also of pragmatic nuances (Lopez-Ozieblo 2018, 2020). This approach is not new, having been used to understand linguistic differences through the conceptualization of path and manner (Brown and Chen 2013; Brown and Gullberg 2010; Stam 2015), time (Casasanto and Jasmin 2012; Chui 2011), or referencing (Gullberg 2009).

Gestures (for the purpose of this study are limited to movements of hands and arms co-occurring with speech) can be mapped onto a continuum depending on their form and relationship with speech (Cienki 2015; McNeill 1992, 2005; Müller 2013). Sign languages and pantomime, usually realized without the need of speech, sit at one end of this continuum. Other more-or-less conventionalized gestures are emblems, gestures codified by a particular society; and beats, baton like movements that mark prosody or stress. Moving along the continuum, there are less conventionalized speech-linked gestures: deictics, which can point at objects/space or even be substituted for words with utterances with spatial deictic meanings, such as 'there', 'this', 'that', 'like this' (Cienki 2015). Next come recurrent gestures (Ladewig 2013) - a new addition to the continuum (Cienki 2015) - "those which can be observed to involve patterns that recur across different contexts" 
(Cienki 2017: 28). A number of recurrent gesture families have been identified (Kendon 2004) such as when indicating the absence or possession of knowledge (palm up open hand [PUOH]) or indicating a repeated element or action (the wrist rotating, a cyclic gesture). At the end of the continuum sit spontaneous gesticulation, movements of the hands and arms which are not codified in any way and depend on the utterance for their meaning (McNeill 1992). These are iconic referential gestures that can mold, draw, re-enact ('as if' doing the action), or represent objects/characters (Müller 2013). In the following section, Examples (9) and (11) depict iconic referential gestures that illustrate parts of the contents of the speech, the shape of the notice and the path and manner of the action respectively. Example (10) is a recurrent gesture with the referential metaphorical meaning of offering additional information to the interlocutor. Its function is pragmatic and it refers to the whole utterance by clarifying it.

Pragmatic gestures like that in Example (10) relate to "features of an utterance's meaning that are not a part of its referential meaning or propositional content" (Kendon 2004: 158). From a functional approach, there are three pragmatic functions: metadiscursive, interactive and cognitive. Metadiscursive functions refer to the organizational flow of the discourse. These include indicating clarifications, salient information, changes in the narrative and overall provide cohesion to the utterance. Interactive functions are those in turn management gestures as well as controlling that information has been received. Cognitive functions affect the contents of the utterance adding complementary information such as the stance of the speaker, the relationship between parts of the utterance, or indicating an inference (Lopez-Ozieblo 2020).

Second language acquisition tends to focus on iconic referential meanings, relying on students' use of their mother tongue (L1) to deduce the pragmatic meaning. Pragmatic meanings in gestures or speech are seldom incorporated in L2 teaching (Romero Trillo 2002). However, to be proficient in a second language it is necessary to know how to integrate all meaning nuances into the communicative act (Stam 2018). Gesture externalizes conceptualization (Lopez-Ozieblo and McNeill 2017) and aids comprehension (Kida 2009). Therefore, explicit instruction focussing on the gestures will be beneficial to interpret speakers' meanings and to produce conceptually accurate utterances (Holme 2009; Hudson 2011; Matsumoto and Dobbs 2017; Saddour 2017; Smotrova 2014). Gestures need to be explicitly incorporated into teaching pedagogies as acquisition requires frequent input and opportunity to produce (Ellis and Larsen-Freeman 2006). In order to exploit the meaning of gestures, their functions, as used by L1 speakers, need to be understood first. 


\section{Methodology}

The objective of this paper is to understand if and how hand gestures indicate the various functions of the marker 'se' in native Spanish speakers. Understanding how natives gesture will provide ELE educators with an additional resource for the teaching of 'se'. The present study focuses on Peninsular Spanish speakers and further examines their use of the marker 'se' according to Maldonado's (1999, 2000, 2008, 2019) CG framework. The methodology followed is qualitative, describing a number of representative examples in detail to explain the relationship between the gesture and the function of the marker. An initial quantitative analysis was carried out to categorize and ascertain the frequencies of the various 'se' functions as observed in the narrations of our participants. This is by no means an exhaustive study, due to the small participant sample and the limitations of the content narrated. However, it identifies some patterns in the co-occurrence of gestures with 'se' that might be useful in a pedagogical context.

The participants were 18 university students, all native Peninsular Spanish speakers, who had answered two calls to volunteer for a study comparing L1 and L2 elements of oral communication (participants' data is given in Appendix A). The specific objectives of the study were not made explicit, to avoid tainting the gesture or oral production of the participants. Participants first engaged with the researcher/confederate by answering a number of personal questions. Then, they watched the first half of the Canary Row (Freleng 1950) episode, from the Tweety and Sylvester television cartoon, and were asked to narrate it with as much detail as possible. Although the researcher was a silent listener, they were also interlocutors in that they were signalling attention and understanding via eye contact, which was maintained throughout. In this extract, Sylvester (a cat) is trying to capture and eat Tweety, a bird living with his owner (Granny), by accessing the flat where Tweety lives and catching him. The cat fails four times, walking in, climbing the outside of a drain-pipe, then the inside of the same pipe and finally pretending to be a monkey, all to get into Tweety's flat. The extract includes a scene where Sylvester swallows a ball that Tweety has thrown down the pipe.

The narrations were transcribed using Praat (Boersma and Weenik 2019) (a speech transcribing software tool) and ELAN (Sloetjes 2017) (a multi-media transcribing tool). The number of utterances with 'se' was counted using Wordsmith. The function of each 'se' was manually coded, following Maldonado's (1999, 2000, 2008, 2019) frameworks, classifying the markers as reciprocals, middle voices or impersonals (there were no reflexives or passives in the corpus). Middle voices were further subdivided into actions of self-care, self-benefit and consumption, and change of emotion, state or physical change. Next, the ELAN transcriptions 
were checked to identify whether there was a gesture co-occurring with the marker (or in close proximity to the marker). Gestures were categorized by their relationship to the marked utterance, verb + 'se'; whether they referred to the marked action iconically or pragmatically (related); or to another aspect of the utterance (unrelated). For example, in Example (9) there is an iconic gesture, G1 (marked as [...] with the stroke underlined, see Appendix B for other annotations used), where the speaker draws the contours of the notice, fixed to the wall, which states that animals are not allowed into the building (Figure 1).
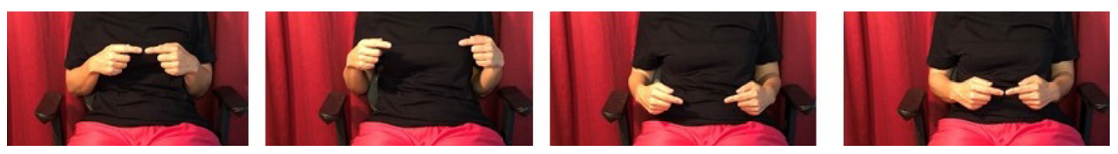

Figure 1: Gesture 1. Referential gesture delineating the contour of the notice.

Example (9) - Participant $3^{1}$

Participant 3 entonces decide bajar corriendo

Literal then decides go.down running

Translation 'then he decides to descend running'

y entrar por la puerta del hotel pero vemos and enter through the door of.the hotel but we.see 'and enter through the hotel door but we see'

que el- $\underline{\text { no }} \underline{\text { se }} \underline{\text { permiten }}$ animales] entonces lo echan a patadas that the- [no SE allowed animals] then he thrown.out by kicks 'that the- animals are not allowed and he is kicked out'

In this example, the gesture is providing additional information as to the existence of a rectangular notice, not mentioned in the speech. As this gesture does not refer to the marked action 'se permiten' (SE allowed), it was categorized as an unrelated gesture.

Other examples of unrelated gestures are pragmatic metadiscursive, or interactional gestures which refer to the organizational flow of the discourse, indicate the turn is kept during a disfluency or check that the message is getting across. Many of these pragmatic gestures are recurrent and include a cyclic gesture ending in a PUOH gesture such as the one described in Example (10). This gesture is further described in Section 5.4 .

1 As the focus here is on the gesture, gesture-transcription convention has been adopted instead of morpho-syntactic glossing. 
Example (10) - Participant 9

...pero: / [la abuela aparece [aunque no se puede ver]]

...but: / [the granny appears [although not SE can see]]

'... but Granny appears although this can't be seen'

[y / le $\frac{\mathrm{da}}{\mathrm{G}} \underline{\text { un }}$ empujón]

[and / to.him gives $\underline{\text { a }}$ push

'and pushes him...'

Gesture 2 (G2): arms rotate outwards from the elbow and hands rotate outwards at the wrist to open up palms, the right extends further than the left (Figure 2).

Related gestures included iconic gestures and beats, gestures that stress parts of the utterance (a metadiscursive function as well) often observed superimposed on other gestures. In Example (11), the iconic gesture is considered to be related to the marked utterance, verb + 'se', as it illustrates the path and also the manner (the speed) of the action. In addition, there is an underlying beat to the gesture, which helps make it salient.
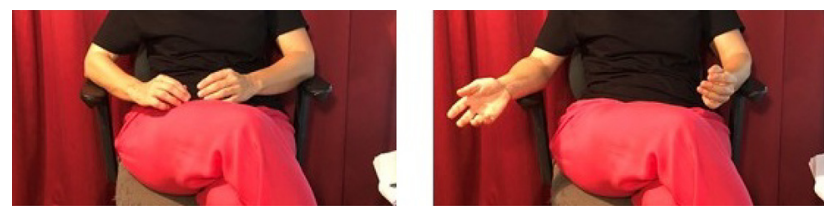

Figure 2: Gesture 2. Cyclic gesture ending in a $\mathrm{PUOH}$ offering gesture.

Example (11) - Participant 15

[entonces en ese momento [justo piolín se escapa G G

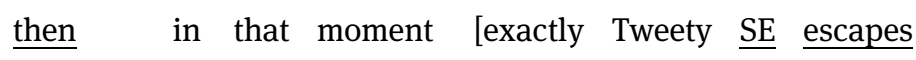
'then at that moment Tweety escapes'

$\underline{\text { [sale }} \quad \frac{\mathrm{de}}{\mathrm{G}} \quad \underline{\text { la }}$ [jaula $y \quad \underline{\text { se }} \frac{\text { mete }}{\mathrm{G} 3}$ para dentro]]] de la

$\underline{\text { [exits from the }}$ [cage and $\underline{\mathrm{SE}}$ goes.in for inside]]] of the 'leaves the cage and goes into the'

hab- para dentro de la habitación

ro- for inside of the room

'ro- into the room' 
G3: The right hand is originally over the left, mid body in the resting position, it lifts up at the elbow to start a sequence of gestures to illustrate the various actions of the bird. G3 is one of the gestures within this sequence where the right arm is extended towards the front-left with the index finger also pointing in the same direction and infusing some extra energy into the action with a slight up and down movement of the hand (see Figure 3).
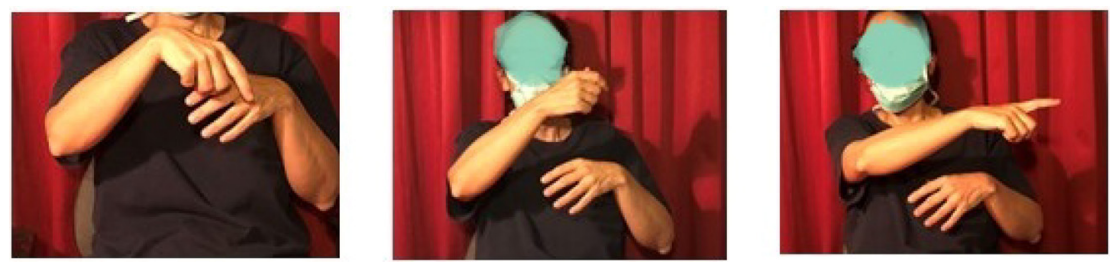

Figure 3: Gesture 3. Referential gesture indicating the path and manner of the escape.

The analysis was carried out by two members of the research team who agreed with all the quantitative results (number and type of 'se' and number of gestures). There were a number of discrepancies in the qualitative analysis of the gesture (whether a gesture was related or not to the marked utterance), giving an inter-rater reliability Cronbach's alpha of 0.98 . The discrepancies were resolved by discussions with a third analyst. After finishing the qualitative analysis, a number of representative examples were selected to illustrate each of the functions of the marker 'se' observed in the corpus.

\section{Results and discussion}

Among the narrations of the 18 participants, there were 152 cases of the marker 'se' in a total corpus of 5186 words. We recorded a mean of 288 words and 8.4 'se' per participant. All participants gestured during their narrations and all but one gestured with some of the marked forms. There was a total of 98 gestures with 'se', with a mean of 5.4 gestures per participant.

Following Maldonado's (1999, 2000, 2008, 2019) framework, over three quarters of the markers were categorized as middle voices $(77 \%$, a total of 117 cases), impersonal uses accounted for 20\% (30), and reciprocal 3\% (5). There were no purely reflexive actions, as defined above. Out of the 152 cases of 'se', almost two thirds $(63 \%$, 96 cases) co-occurred with a gesture. Impersonals occurred with gestures in less than two fifths of all impersonal cases (37\%, 11 cases out of 30 ). However, none of the gestures observed were related to the marked action. Two thirds of middle voices co-occurred with a gesture ( $68 \%, 80$ cases out of 117$)$. Of 
these 80 cases, $75 \%$ (60) were related to the marked action. Reciprocals were observed with gestures in all five cases, all of which were related (Figure 4).

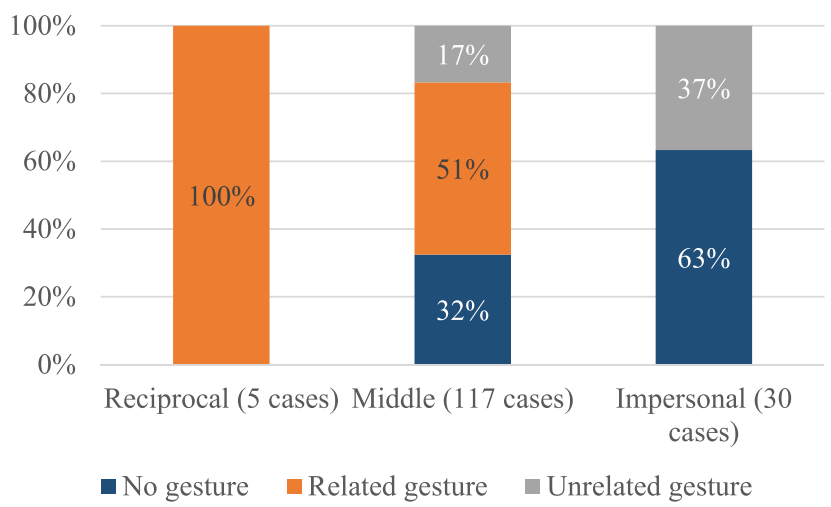

Figure 4: Type of 'se' and gestures co-occurring with them.

\subsection{Reciprocal 'se'}

There were just five cases of reciprocal utterances with 'se' in the corpus; encontrarse, intercambiarse, mirarse, verse and vigilarse ('meet', 'exchange', 'look', 'see' and 'monitor each other'). All cases occurred with gestures related to the meaning of the 'se' + action and, most importantly, were represented with both hands.

Example (12) - Participant 1

...ly se/ hm ven $\left.\frac{\text { el }}{\underline{u}} \underline{\underline{u n o}} \underline{\underline{\text { al }}} \quad \underline{\text { otro }}\right] \ldots$

...[and SE / hm see the one to.the other] ...

'... and they see each other...'

G4: Both hands open facing each other in the frontal axis. During the 'se', they come down from near the face to shoulder height, the right hand lifts and drops at the wrist and then the left repeats the movement (Figure 5). These are deictic gestures where each hand represents a character.
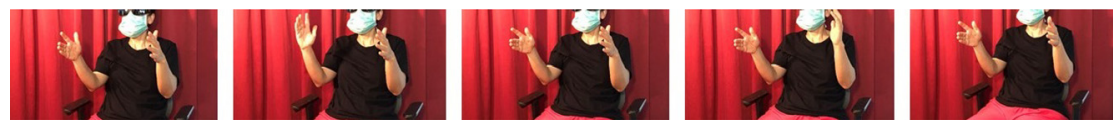

Figure 5: Gesture 4. Reciprocal 'se'. 
Reciprocal utterances have a plural subject which is both agent and patient, indicating a symmetric action. The plurality of the subject seems to be embodied in the use of both hands, each representing different characters which are equal in size, position and prominence (as illustrated by the gesture). Usually the hands are positioned in the frontal axis (left-right) indicating the equal standing of the characters. On the other hand, a sagittal axis position (front-back) would stress the prominence of the character closer to the body. Should this axis be used in reciprocal actions, it is anticipated that the gesture will include a movement where the hands switch positions. In the teaching of reciprocal actions, the key lies in the symmetric nature of the action as it concerns the agents/patients. Gestures can reinforce this concept stressing the equality of the characters involved.

\subsection{Middle voices}

The majority of 'se' in the corpus were middle voices (77\%, 117 cases out of 152). These were likely to occur with a gesture (68\% of all middle voices). Maldonado (2000, 2008, 2019) differentiates between self-directed or self-benefit actions and those involving a change of emotional, physical or locative state. We follow this categorization, differentiating further between the various types of verbs of change.

\subsubsection{Self-care: Inalienable possessions}

This category is one of the most contentious, even among CG linguists, often being grouped with reflexives (Castro Castañeda 2004b; Torres González et al. 2018), at least for pedagogical purposes. In the corpus, self-care actions that require the marker 'se' included four structures: ponerse 'put on', three cases, and vestirse 'dress'. In three cases, the gesture points towards the body, see Example (13). A fourth unrelated gesture, with ponerse, was a recurrent gesture associated with a metadiscursive function (Lopez-Ozieblo 2020).

Example (13) - Participant 17

le roba la ropa $[y$ se viste como] si él fuera un mono $\underline{\mathrm{G} 5}$

from.him steals the clothes [and $\underline{\mathrm{SE}} \underline{\text { dresses }}$ as] if he was a monkey 'steals his clothes and dresses up as a monkey'

G5: The left hand lifts from the lap and circles up and towards the body, palm towards the body, then returns to lap (Figure 6). 

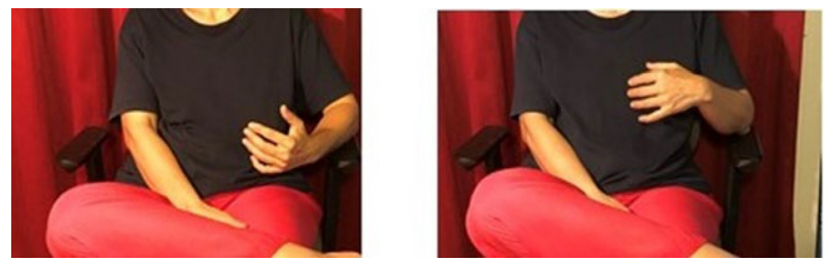

Figure 6: Gesture 5. Self-directed action vestirse.

In these cases 'se' acts as a direct object that refers to the parts of the body that will be covered by clothing. These parts (trunk, arms, legs) are not specified as they are lexicalized within the verb (dress) but it is understood that they are involved in the action (Maldonado 2019). Perhaps speakers gesture to the body to stress the unspecified lexicalized meaning.

Another type of self-care actions are those that pertain possessions which are conceptualized as inalienable, such as clothing and accessories. These are considered to be inactive objects which require 'se', as in Example (14) where the speaker describes how the cat lifts his hat off (levantarse) to thank Granny. This expression occurs twice in the corpus, both times with the same gesture.

Example (14) - Participant 12

$\left[/ / /\right.$ se $\frac{\text { levanta }}{\mathrm{G} 6}$ el sombrero $y$

$[/ / / \underline{\mathrm{SE}} \underline{\text { lifts }} \underline{\text { the }}$ hat and 'lifts his hat and'

[es cuando $\frac{\text { se }}{\mathrm{G}} \underline{\text { le }} \underline{\text { ven }}$ la:s orejas del gato///]]

[is when SE him see the: ears of.the cat///]] 'that is when the cat's ears are seen'

G6: From a mid-body rest position the left arm in a loose cupping, palm facing down, lifts up from the shoulder to above the head it stops briefly and the whole arm continues to be raised with the wrist rotating upwards until the hand is well above the head the palm facing in (Figure 7).
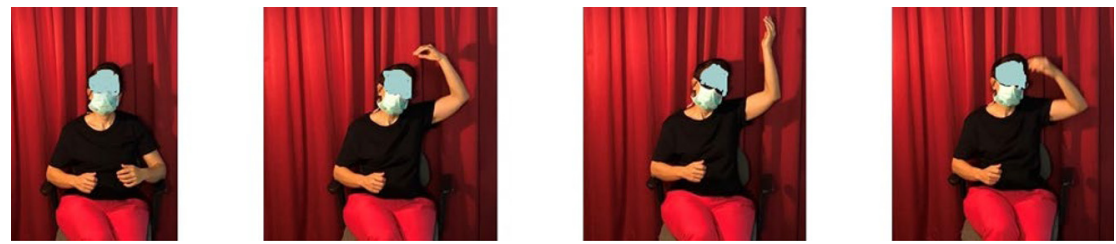

Figure 7: Gesture 6. Self-directed action se levanta. 
The gesture is considered an emblem in many societies, as it is codified with the specific meaning of doffing one's hat. It is unexpected to observe gestures with routine self-care actions - shaving, showering, washing one's hands. If there are gestures, one possibility is that their emblematic nature triggers their use automatically with the speech - akin to raising a thumb when agreeing with someone. If this prediction is right then, we would not expect speakers to gesture with these actions, due to their routine nature, except in cases where emblems exist for them.

\subsubsection{Consumption (self-benefit)}

Concrete and abstract consumption verbs, such as eat, swallow, drink, smoke or read, among others, also belong within the category of self-benefit actions. These structures have alternative forms that do not require the marker. The corpus contained 17 cases of consumption actions, all related to ingesting (a bowling ball thrown by Tweety, which Sylvester swallows). Most utterances (76\%) co-occurred with gestures and just two seemed to be unrelated.

Example (15) - Participant 2

le pilla en medio del fregao [se $\underline{\text { la }} \underline{\text { traga }}] \ldots$

G7

him finds in middle of.the action $[\underline{\mathrm{SE}} \underline{\text { it }} \underline{\text { swallows}}] \ldots$ 'finds him in the middle of the action swallows it ...'

G7: Hands by lap, left hand over right hand facing in. They both open, palms facing up and back to rest position in a quick gesture (see Figure 8).
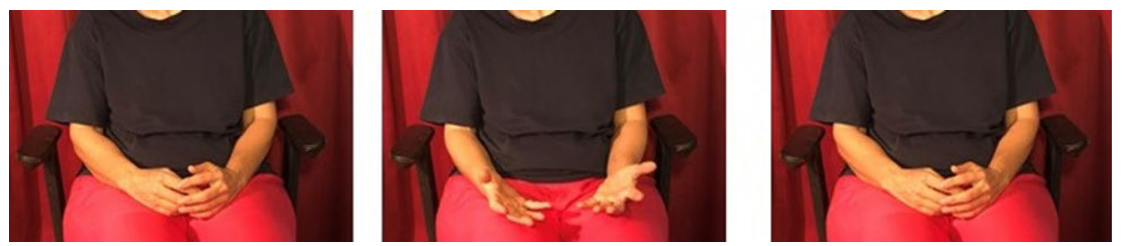

Figure 8: Gesture 7. From the rest position by the lap there is a quick gesture palms rotate to face upwards and back to rest.

Example (16) - Participant 18

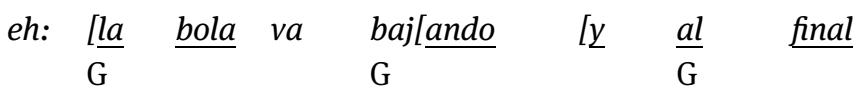
eh: [the ball goes do[wnwards [and at.the end 'eh the ball goes down and at the end' 
por supue- eh [se $\underline{\text { la }}$ tragal]]] ////// y:

of cour- eh [ $\underline{\mathrm{SE}} \underline{\text { it }} \underline{\text { swallows}}]]]] / / / / / /$ and:

'of cour- eh it swallows it and'

G8: Both elbows resting on the arm-rests, hands by the upper chest, palms facing down and in. The right hand is raised slightly, fingers bunched together and wrist turned towards the body, and then the wrist turns in so the hand descends in a straight line (see Figure 9).
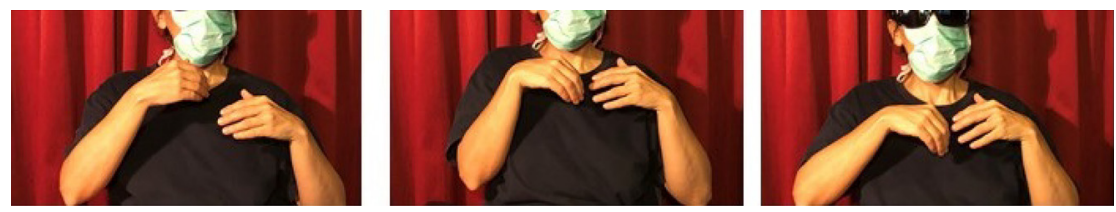

Figure 9: Gesture 8. Right hand indicates the path of the swallowed ball.

Ingesting verbs are transitive verbs that acquire either an expletive or a telic nuance when used with the marker 'se'. The gestures observed with most cases are referential, 'as if taking something into the body' but they are also pragmatic cognitive, working side by side with the marker, to highlight how the object consumed is brought into the dominion of the subject and exploited fully, often quickly and efficiently (Maldonado 2008). In Example (16), the gesture illustrates how the ball is brought into the dominion of the cat, and other gestures also point specifically to the mouth, stressing the ingesting element. On the other hand, the gesture observed in Example (15) marks the speed of the action and its completion, it is a quick opening and closing of the hands. These gestures seem to infuse the action with an energy not observed in the self-directed gestures. The full exploitation of the object needs to be marked with a 'se' and also by the syntax, either a determinant to note that a full entity is affected by the action, or a complement to the direct object that gives the same meaning (Sánchez López 2002). We strongly suggest that the pragmatic meaning of consumption middle voices ought to be explicitly taught to Spanish learners, together with their form. The gesture, likely to refer to the speed of the action or the totality of the object consumed, will give students an important clue as to why the marker is added.

There was an additional case of a self-benefit action aprovecharse 'take advantage', which occurred with a non-related gesture. In this case, the 'se' is not necessary, its use stresses the benefit to the subject of bringing the object into its domain. 


\subsubsection{Emotional and mental changes}

Middle voices can also be used to indicate an emotional or mental change, stressing either the suddenness of the event or, again, the full involvement of the subject, the action becoming more energetic. Among the cases in the corpus there were 18 utterances with the locution darse cuenta, two ocurrirse, one percatarse and one iluminarse, all with the same meaning 'realise' in this context. There was also one despistarse 'get distracted'. The non-marked locution dar cuenta means 'to end something/someone', (Real Academia Española 2006); percatar (without the marker) has fallen into disuse; and despistar has a different meaning ('mislead someone') from despistarse as does ocurrir 'happen'. Iluminar 'light up something' contrasts with iluminarse used here in the metaphorical sense of 'a light went on in his brain'. Out of these 22 cases, only three co-occurred with related gestures. The marker is not an option in any of these cases so it is not adding information about effort, speed or telicity. It is likely that gestures are not added for the same reason. Example (17) is one of the two exceptions of marked utterances with gestures, both referring to the discourse rather than the marked action:

Example (17) - Participant 6

pero está la abuela en el salón]

but is the granny in the living-room]

'but granny is the sitting room'

$y: \quad / y: \quad\left[l o-\quad \frac{l o}{\mathrm{G}} \quad \underline{v e} \quad y \quad\left[\underline{\text { se }} \frac{\text { da cuenta }}{\mathrm{G} 9}\right.\right.$ que: /...

and: / and: [him- him sees and [SE realizes that: /... 'and she sees him and realizes that...'

G9: Both hands palms facing up, right hand higher than left hand, both extend the fingers further (the left thumb is holding a tissue) and repeat a small circular movement at the wrist (Figure 10).
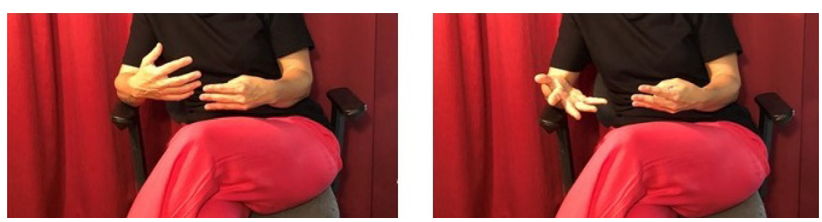

Figure 10: Gesture 9. Verbal locution with 'se'.

In Example (17), both hands are engaged, although the right hand dominates, and the fingers are extended out as if to indicate clarity. This is a recurrent 
metaphorical gesture, a PUOH, which could be interpreted here as having more knowledge, represented by the spreading of the hands, an illustration of 'to realise'. The PUOH is associated with the acquisition and/or lack of knowledge and can have various pragmatic meanings (Kendon 2004; Lopez-Ozieblo 2020; Müller 2004). The small repeated movement is interpreted as belonging to the recurrent family of gestures related to 'again', a cyclical gesture (Ladewig 2011). The gesture observed in the other case is similar, more likely to be emphasizing the recurrent nature of the event (it is by now four times that Granny realizes the cat is after the bird) than the mental change depicted. In these cases, the actions are not controlled directly (consciously) by the subject.

There were other three utterances denoting changes of mental states: creerse and pensarse ('believe', 'think') where there is more subject involvement. These were marked with 'se' and also with gestures. As in Example (17), both hands formed these gestures:

Example (18) - Participant 3

[se pensaban que era un mono] G10

[SE thought that he.was a monkey] 'they thought he was a monkey'

G10: Hands in loose fist by mid body, index fingers extended, both hands rotate slightly towards the body, the index fingers pointing inwards (Figure 11).
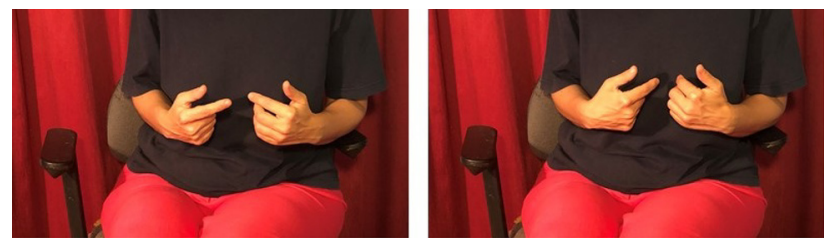

Figure 11: Gesture 10. Emotional and mental changes se pensaban.

In Example (18) and the other two cases with pensar and creer, the marker is not necessary (in some Spanish variations it is ungrammatical). Its use can indicate that the thought is formed by the thinker without justification, such as in the expression:

$$
\begin{array}{lllll}
\text { Se piensan } & \text { que } & \text { soy } & \text { tonto } \\
\text { SE they.think that } & \text { I.am } & \text { stupid }
\end{array}
$$

'They think I am stupid' (implies a pragmatic cognitive meaning of 'they are wrong, I am not stupid').

The gesture co-occurs with the 'se', adding salience to the 'experiencer' of the thought, indicating the involvement of the subject/experiencer in coming up with 
the thought. This is illustrated by the hands pointing towards the speaker's body. This is a deictic gesture stressing the involvement of the subject/s (themselves) in carrying out the action, the gesture highlights the inadequacy of those who thought Sylvester could be a monkey. In addition, the use of both hands indicates the full involvement of the subject/s (observed in all cases).

The expressions found in the corpus conveying emotional internal changes include single occurrences of sorprenderse ('become surprised'), asustarse and frustrarse ('become scared' and 'become frustrated'), and desquiciarse ('go crazy'). Although these emotional changes are out of the subjects' control, they are the consequences of unexpected external inputs, they involve a large internal shift of emotional energy resulting in a high level of engagement. This is indicated by the 'se', which is necessary in these constructions. Example (19) illustrates how the two hands are used to express the extreme of the emotion, conveying a high energy load.

Example (19) - Participant 16

...y vemos cómo silvestre está buscando a piolín con unos and we see sylvester is looking for tweety with some prismáticos

binoculars

'... and we see Sylvester looking for Tweety with a set of binoculars'

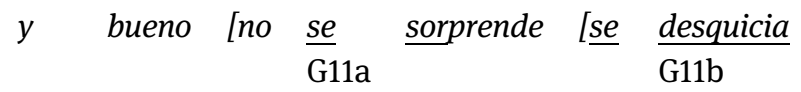

and well [no SE surprised $\underline{\text { SE }}$ goes.crazy

'well he is not just surprised he goes crazy'

cuando ve que piolín también lo está buscando when sees that tweety also him is looking.for 'when he sees that Tweety is also looking for him'

G11a: Both hands from lap rotate upwards, palms facing the body, stop midrotation to stress the first 'se'.

G11b: The outwards rotation is continued with the hands opening up, fully stretched, in a Palm Up Open Hand (PUOH) gesture (see Figure 12).
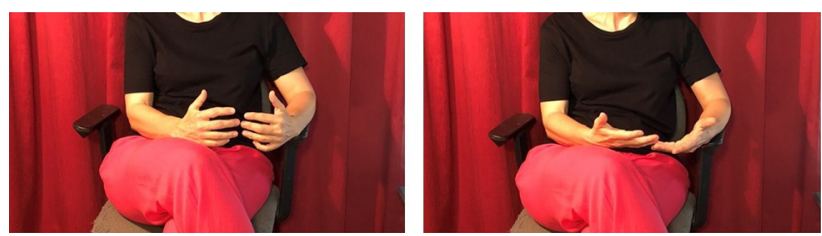

Figure 12: Gesture 11. Emotional and mental changes se desquicia. 
The gestures observed with these and other verbs of cognitive change are often PUOH, performed with two hands. In Example (19), a verb of emotion, there is an intermediate stressing gesture, occurring half way in the realization of the PUOH but in neither case are the hands relaxed, illustrating the intensity of the emotion. Some of these expressions are repeated more than once by the same speaker. This is likely to affect the gesture, which diminishes in energy and frequency with repetitions (Gerwing and Bavelas 2004). A larger corpus with first-time utterances only would be needed to explore whether the two hand $\mathrm{PUOH}$ can be associated with these changes of cognition and emotion.

\subsubsection{Verbs of change (focus on the position of the body)}

As with verbs of emotional and cognitive change, in middle voices with changes of body position, location or state, 'se' marks the change, not the circumstances or the forces causing the change, stressing the end result - the change of state - rather than the process. Actions that refer to changes in the position of the body are always marked and include actions such as: levantarse, sentarse, estirarse ('to get up', 'to sit', 'to stretch'). There were three utterances in the corpus under this category, two with mecer and one with balancear (both meaning 'to rock' in this context). There are two utterances of mecer by the same speaker, however the second mention does not have a gesture as it is an anaphoric nature referring to the mecer action mentioned previously. For the two gestures representing the action of rocking, both hands are used to indicate the path (forward and back) and the manner (slow and uniform) of the motion.

Example (20) - Participant 9

\begin{tabular}{|c|c|c|c|c|c|}
\hline donde & piolín] & {$[/ \underline{s e}$} & está & balanceando & tranquilamente \\
\hline$G$ & & & & G12 & \\
\hline where & tweety & [ / $\underline{\mathrm{SE}}$ & is & $\underline{\text { rocking }}$ & calmly \\
\hline
\end{tabular}

'...where Tweety is calmly rocking himself'

[/llega otra $\frac{\text { vez }}{G}$ la abuela

[/arrives another time the granny when the granny arrives again ...' 
G12: Both hands face each other to start with, fingers somewhat extended but right hand forefinger is more salient, during the pause preceding the 'se' the right hand begins to swing back and forth, towards the body and away, with the left hand following slowly (Figure 13).
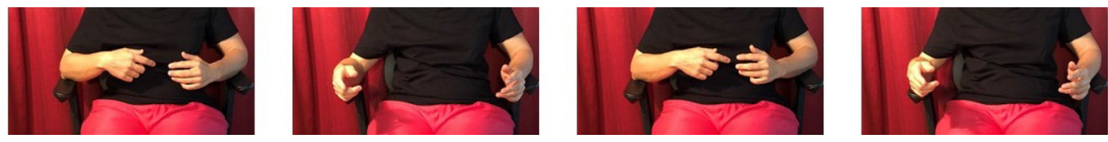

Figure 13: Gesture 12. Change of body position 'se'.

These actions are iterative, lending themselves to repeated gestures that mark their durative profile (as noted by one of the reviewers). Changes in body position tend to be routine actions (to sit, to kneel, to lie down). Therefore, gestures cooccurring with them, if there are any, are likely to highlight the manner of the action as the path is often fixed.

\subsubsection{Verbs of change (focus on the aspect)}

The focus on the end result is also part of the meaning in Example (19), however, it is much clearer in verbs with aspectual properties that do not require 'se', such as llegar ('arrive'), where the terminating aspect is more noted or ir ('go') with a stronger focus on the initiation of the action. 'Se' reinforces the "core properties of the verb" (Maldonado 2000: 160), stressing the inceptive/culminative aspect of the action. There were six examples of such verbs in the corpus: irse ('go'), three cases; subirse ('ascend'), two cases; and salirse ('exit'), one case. The core properties of the latter four focus on the terminated action. All of the above co-occurred with a related gesture.

Example (21) - Participant 1

...[pero piolin/ coge se $\frac{\text { escapa] }}{\mathrm{G} 13 \mathrm{a}}$ [/se sale $\frac{\mathrm{de}}{\mathrm{G} 13 \mathrm{~b}} \underline{\text { la }}$ jaula...

... [but tweety/ takes SE escapes] [/SE exits of the cage...

'...but Tweety escapes leaves the cage ...'

G13a: both hands, right hand on top of left hand by head, palms facing down downwards rotation and back up (Figure 14a).

G13b: Hands by head, left hand over the right hand cupping the fist. Right hand moves up, forcing open the left which slides down the right wrist while the right hand opens after which the palms of both hands come together (Figure 14b). 

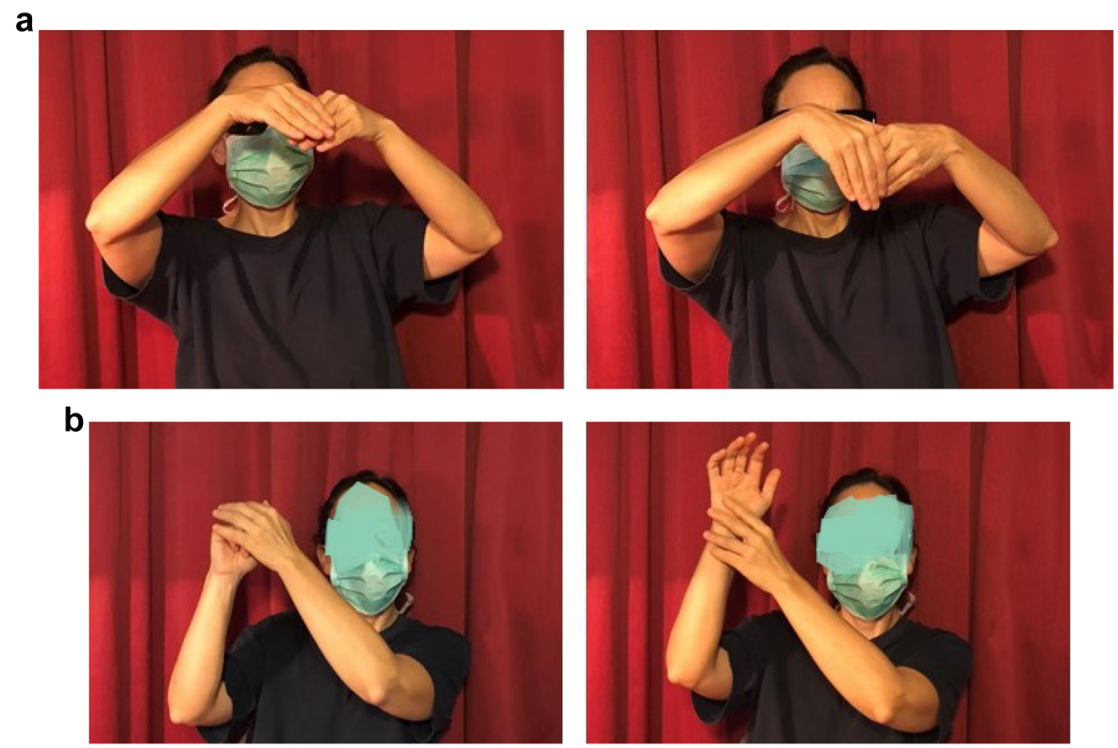

Figure 14: a. Gesture 13a. Verbs of change se escapa. b. Gesture 13b. Verbs of change se sale.

The gesture is not synchronous with the marker but with the verb, reinforcing Maldonado's idea (2000) of the marker not adding meaning but highlighting the existing properties of the verb. The referential gestures, stressing the result of the action (not the process), illustrate the action of flying free from the cage (starting point), in (13b) one hand is tracing the path of the bird while the other represents the cage. In certain Spanish varieties, the marked expressions with ir ('go'), venir ('come'), llegar ('arrive') are common and very confusing to learners who do not understand why 'se' is added. In all these cases, there is a high level of energy, the actions are expected to be dynamic, if not sudden and fast. By illustrating the action with a gesture this energy can easily be highlighted, together with the terminating/initiating aspect of the verb, allowing for a more comprehensive conceptualization of the action.

\subsubsection{Verbs of change (full involvement)}

In some of the above verbs of change, 'se' stresses their aspectual properties but it also conveys a sense of the subject's full involvement in the action (exit). The more involved the subject is in the action, the more likely is the addition of 'se' as an indication of the level of energy invested in the action. This is illustrated by the fact that actions requiring the involvement of the whole body are usually marked, such as colarse ('sneak in'), six cases in the corpus; meterse ('insert'), eight cases; escaparse ('escape'), two cases; esconderse ('hide') two cases; acercarse ('get 
close'), three cases; and agarrarse ('hold onto'), one case. With these actions the expectation is to observe related gestures in most cases as there is a high degree of energy being conveyed through the 'se' which should be externalized through the gesture as well. Indeed, most of these verbs co-occurred with a gesture (67\%). Out of the eight cases without a gesture, half were repetitions where salience would have diminished by reason of the reiteration and a full gesture would be less likely (Gerwing and Bavelas 2004). The gestures observed are all related and they all add information about the path or the manner of the action, see Example (11) as well where one hand is employed to represent the whole body going into the drain.

In most of these cases, the non-marked forms are not possible. Speakers could have selected non-marked alternatives, such as entrar ('enter') instead of meterse / colarse, losing the sense of effort (energy) and deceptiveness of meterse and colarse. The utterances call for gestures to highlight that energy.

\subsubsection{Verbs of change (metamorphosis)}

Although Maldonado (2019) does not include this as a category, we suggest that certain verbs of change imply a metamorphosis of some sort, which sits somewhere between controlled and non-controlled changes. This category includes verbs such as convertirse or hacerse ('become'). In our corpus, we found other metamorphosis related actions when participants describe how the cat pretends to be a monkey using the expressions hacerse pasar ('pretend to be someone else'), six cases, and disfrazarse ('disguise oneself'), 11 cases. Both structures imply full involvement and quite a controlled change but they lack the physical movement implied in other verbs of change. The initial analysis of disfrazarse as a self-care action was revised as its meaning implies more than just dressing up in specific clothes but also pretending to be another entity. In both cases 'se' is necessary, but the 12 gestures observed are not usually related to the action - only three out of the 12 gestures are related. Example (22) shows one of those three related gesture that illustrates the involvement of the self in the disguising action.

Example (22) - Participant 9

el silvestre espera para coger al- al the sylvester waits to grab to.the- to.the 'Sylvester waits to grab the'

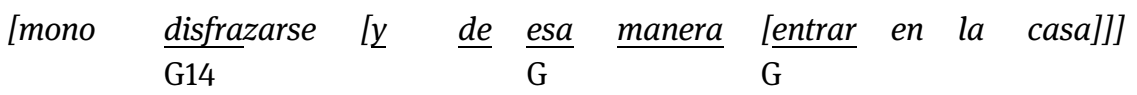
[monkey disguise.SE [and of that manner [enter in he house]]] 'monkey and disguised in this manner (dressed up as a monkey) enters the house...' 
G14: Hands close together by the lap in loose fists they rotate at the wrists towards the body (Figure 15).
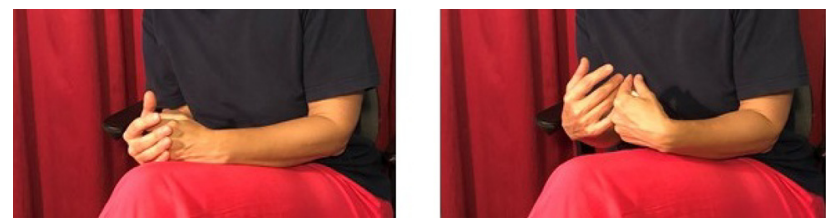

Figure 15: Gesture 14. Self-directed action disfrazarse.

The other nine non-related gestures were mostly gestures of a metadiscursive nature (except for one where the participant illustrated the walk of a monkey), similar to the one observed in Example (10) (palm rotating outwards) - a cyclic gesture which is often observed when sequencing events (Ladewig 2011). These non-related gestures were carried out with just one hand while the related gestures involved both hands.

In our corpus, we had also come across the verb parecerse ('resemble'). It had initially been categorized as a reciprocal - based on the false premise that if $\mathrm{A}$ resembled $B$ then $B$ would also resemble $A$ - but one of the reviewers pointed out that unlike reciprocals, parecerse does not have two independent active participants and should be categorized as a middle voice "without volition or control" (Reviewer). Although parecerse lacks the obvious metamorphosis of convertirse, it has in common with it the idea of the subject being related to another group (Moreno Burgos 2018) - in the case of parecerse a relation to another entity. Moreno Burgos gives the following example: "Santiago Bernabéu se convirtió en presidente del club” (2018:37) ('Santiago Bernabéu became the club's president') whereupon Bernabéu was included in the class of presidents. There was only one case of this type in the corpus. It occurred with a weak one-hand gesture that pointed to the speaker's body. Had it been a reciprocal, we would have expected both hands to be engaged and equal in their representation.

\subsubsection{Verbs of change (unexpected changes)}

There is one other case of verbs of change where the subject has no control over the action and yet there is a high level of energy being conveyed. These are actions indicating counter-natural events. They differ from the above category in that they indicate actions that break the natural order of the universe, such as caerse ('fall') for a person, found four times in the corpus. Caer, unmarked, suggests a normal, expected, action but an accident when marked. As such, we would expect caerse to 
be stressed by a gesture to mark the fall and the energy associated with it. We observed relevant gestures in three of the four cases, see Example (23). The fourth case was a repeated utterance that occurred without a gesture.

Example (23) Participant 14

la abuela le: le le da co:n un paraguas creo que era

the granny him: him him hits wi:th an umbrella I think that was

'the granny hits him with an umbrella, I think it was an umbrella'

$[/ / / / / y:$ se cae por la venta]na se cae pabajo G15

[///// and: SE falls throug the windo]w SE falls to.downwards 'and falls through the window falls downwards'

G15: Hands in resting position mid body, the right arm moves at the shoulder towards the left, elbow bent and then it is rotated at the elbow towards the right, palm open facing up, indicating the trajectory taken by the cat (Figure 16).
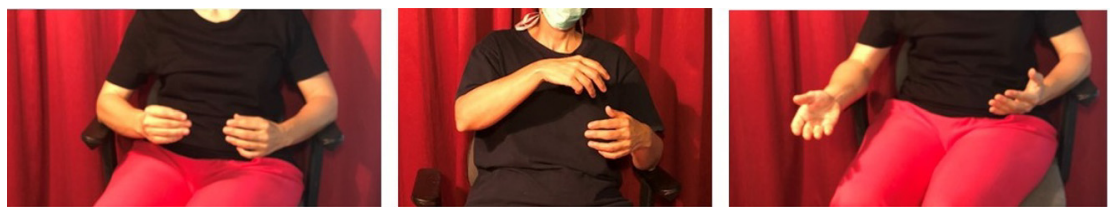

Figure 16: Gesture 15. Path of the fall from the window.

The gesture indicating the path and manner of the fall coveys a high level of energy (through the speed and full engagement of the hand). Although the corpus only provides a limited number of cases, we would expect to see full gestures with other verbs denoting accidental actions.

There were also nine cases of encontrarse (one meaning 'find oneself physically somewhere' and eight meaning 'bump into someone'), which we also include under this category as there is an implication of lack of control by the subject. The marked form has a different meaning from that of the unmarked verb ('to find someone or something after searching'), so it is necessary. With actions indicating unexpected events, we would anticipate a gesture to make them salient, even if only a beat stressing it. However, the utterances with encontrarse did not usually occur with gestures - just two, both metadiscursive PUOH gestures, similar to that in Example (10). We believe this might be because, while usually there is a certain degree of unexpectedness in encontrarse, in this context this differs from that of caerse in that encontrarse could be considered an almost 
expected event: as Sylvester is looking for the bird, it is quite likely that he will find him. There is no additional energy (internal or external) associated with the action.

As the subjects' involvement is reduced, and with it the level of self-energy infused into the action, there is no gesture stressing it.

\subsubsection{Other middle cases}

Maldonado (2019) mentions another use of 'se' with verbs that verbalize emotions or feelings (complain, regret). We found one example in our corpus, vengarse ('get revenge') which we believe should be included within this category as it verbalizes emotions and their consequent actions. However, the gesture observed is not related to the action as the speaker places the word vengarse in a set of imaginary quotation marks. This gesture is an emblem, conventionalized to indicate that the chosen word might not be quite correct or appropriate. With these types of verbs, the expectation would be to see beat gestures stressing their emotional energy.

\subsection{Impersonal 'se'}

There were 30 cases of impersonal utterances using 'se' with decir, entender, permitir, ver, admitir and poder ('say', 'understand', 'allow', 'see', 'admit' and 'can'). In 19 out of the 30 (63\%) impersonal cases recorded there was no gesture, out of the remaining 11 gestures none related to the marker, instead they usually managed the flow of the narration, as in Example (10). The exception was Example (9) where the gesture was referential, illustrating the shape of the sign.

The gesture in Example (10) is not synchronous with the marker and it does not seem to illustrate the impossibility of seeing the Grandma or the push she is about to administer the cat. Instead, the gesture stresses the discursive meaning of 'although' with a recurrent gesture that presents a new idea to the interlocutor. While this is a referential gesture, metaphorically placing a piece of information on the palm of the hand and offering to the interlocutor, it is also a pragmatic metadiscursive gesture commenting on the narration by clarifying a point, for the interlocutor (giving it also an interactive function) (Kendon 2004, Lopez-Ozieblo 2020).

The analysis of impersonal structures with 'se' indicates that gestures seldom co-occur with the marker and when they do, they are unrelated to the marked 
utterance - synchronicity with the exact speech unit is not always found (Kendon 2004), therefore the whole gestural phrase is considered. Most of the gestures observed were of metadiscursive - except the one illustrated in Example (9). These were used by the speakers to manage the flow of the narration indicating the start of the action or commenting on it, as in Example (10).

Impersonal utterances lack an explicit subject, the predicate refers to one or a group of unspecified people (Sánchez López 2002) and the utterance does not need to imply a change of state (Castro Castañeda and Melguiza Moreno 2006). In Spanish, the speaker can reinterpret the scene to reduce the subjects' responsibility (for a number of reasons, see Maldonado 1999) at the same time implying the involvement of the subject or someone other than the subject. Therefore, the salience of this type of sentence is relatively low. Making them less likely to co-occur with gestures, which are salience markers themselves (McNeill 2015). When gestures are employed, they are likely to refer not to a specific action but to the discourse. These gestures, identified in speakers of different cultures in different contexts (Ladewig 2013), are often recurrent gestures already used by learners in their L1 and likely to be employed in L2 narrations as well (LopezOzieblo under review).

\section{Summary}

Our corpus suggests that speakers use gestures with 'se' structures to indicate the full involvement of the subject in the action (mentally or physically) and to highlight actions that involve a high level of energy. These include: reciprocal structures, where the subject is fully involved; middle voices of self-benefit, mental emotional changes, physical changes controlled by the subject and unnatural events. Despite the idiosyncrasy of gestures, those co-occurring with marked high energy utterances tend to be related to the action being described. They usually illustrate it providing additional information (path, manner) or indicating its contribution to the utterance (metadiscursive or cognitive pragmatic functions).

There are other functions of 'se' that do not convey a high energy change or where the subject's involvement is not clear. In these cases, we are less likely to observe gestures. These functions include: middle voices of self-care, mental changes related to realization, physical changes not wholly controlled by the subject (metamorphosis) and unexpected (but not unnatural) events; and impersonal structures. If gestures occur, they are not usually related to the action, as is 
the case with impersonal utterances. When related hand movements occur, these tend to be emblems (codified gestures) which do not add information to the utterance, as is the case with routine self-care actions.

Although our corpus is limited, we believe that reciprocal utterances will be more likely to occur with related deictic gestures referring to the plurality of the subject/s by using both hands. In reciprocal utterances, the two hands would represent the symmetric nature of the various characters involved, which are given equal importance by presenting them in the frontal axis. Although our study did not yield any cases of purely reflexive utterances, we suspect that these are more likely to co-occur with iconic gestures that illustrate the two different spaces involved. As the occurrence of reciprocals and reflexives in natural speech is relatively low, these predictions will require a large corpus to be tested. It is recommended that such a corpus should include a variety of contexts.

\section{Conclusion}

This study analysed the oral production of native speakers of Spanish, finding that these speakers' gestures vary depending on the various functions of the marker 'se' and its level of energy and subject involvement. The analysis was based on the Cognitive Grammar (CG) framework proposed by Maldonado (1999, 2008, 2009, 2019), an approach already adopted by a number of Spanish language pedagogues (Castro Castañeda 2004a, 2004b; Torres González et al. 2018). We suggest that gestures should be included as a pedagogical resource in ELE contexts to facilitate the interpretation and processing of the meaning added by the marker.

Linguistic items are construed in relation to each other, giving information about how a scene is conceived and portrayed by the speaker through the level of specificity, focus, or his/her perspective (Cienki 2015). Being able to process accompanying gestures helps second language learners to clarify these points (Holme 2009). Gestures can indicate what "facets of conception are active when" (Langacker 2008: 250) providing a visual cue as to what aspects of the utterance require attention. In the case of structures with 'se', any additional information is key to interpreting its meaning. In addition to the intrinsic difficulties of 'se' in Spanish, L2 speakers also have to deal with interferences from mother tongues (L1), where equivalents might not exist or if they do, as in the case of other romance languages, there might be grammatical or lexical differences in the use of the 
marker (Renau 2015). It is thus not surprising that even high proficiency students struggle with the marker.

Teaching students to highlight the energy/involvement added by the marker with a related gesture will help students strengthen their conceptualization of certain functions, in particular self-benefit and telicity structures. Teaching gestures should include the use of one or two hands, their timing with the utterance, the form of the hand as well as possible iconic representations. Simple examples could include: using both hands to eat a cake with SE ha comido la tarta ('he has eaten the WHOLE cake'); gesturing the starting point with SE fue a su casa ('he left HERE to go home'); using fully extended hands to indicate fear with SE asusto ('he was [HIGH ENERGY] scared'); using both hands to represent different mental spaces with SE vio en el espejo ('she [ONE HAND] saw herself in the mirror [SECOND HAND]'). In oral assessments, asking students to gesture with 'se' might facilitate the evaluation of their command of the marker as conceptual mismatches will be easier to spot in the gesture.

We do not claim that gestures alone will suffice to clarify the function of the marker but they can provide additional information to process it, in particular, to understand the level of energy infused by the 'se'. We believe a teaching methodology combining Maldonado’s framework (2019) and gestures might go a long way to facilitate the understanding of 'se'.

Acknowledgements: This study would not have been possible without the help of the participants in the various studies conducted. I would like to mention you all by name as your contribution has been invaluable, but I did promise anonymity. Thank you to all. Thank you also to the reviewers and editors who helped to improve previous versions of this paper.

Research funding: This study was partly funded by the Early Career Research Fund of the Department of Linguistics and Modern Languages, University of Huddersfield, and the Early Career Scheme of the Faculty of Humanities of the Hong Kong Polytechnic University. The PI of the project is a member of the Research Centre for Professional Communication in English (RCPCE) of the Department of English of the Hong Kong Polytechnic University, the mission of which is to pursue applied research and consultancy to deepen the understanding of professional communication and to better serve the communicative needs of professional communities. The PI is also member of the Research Centre for Language Teaching and Learning (RCLTL) of the Department of English Hong of the Kong Polytechnic University. This project is intended to fulfil in part their missions. 


\section{Appendix A: Participants' data}

\begin{tabular}{llrrrrrr}
\hline & Gender & $\begin{array}{r}\text { No. } \\
\text { words }\end{array}$ & No. of & $\begin{array}{r}\text { se/100 } \\
\text { words }\end{array}$ & $\begin{array}{r}\text { No. of gestures } \\
\text { (with se) }\end{array}$ & $\begin{array}{r}\text { No. of } \\
\text { gesture/se }\end{array}$ & $\begin{array}{r}\text { No. related } \\
\text { gestures }\end{array}$ \\
\hline Participant 1 & Male & 289 & 11 & 3.81 & 2 & 0.2 & 2 \\
Participant 2 & Male & 402 & 12 & 2.99 & 9 & 0.8 & 8 \\
Participant 3 & Male & 382 & 11 & 2.88 & 10 & 0.9 & 5 \\
Participant 4 & Male & 286 & 6 & 2.10 & 2 & 0.3 & 1 \\
Participant 5 & Female & 391 & 16 & 4.09 & 9 & 0.6 & 7 \\
Participant 6 & Female & 169 & 2 & 1.18 & 2 & 1.0 & 2 \\
Participant 7 & Female & 142 & 3 & 2.11 & 0 & 0.0 & 0 \\
Participant 8 & Female & 185 & 6 & 3.24 & 5 & 0.8 & 4 \\
Participant 9 & Female & 319 & 12 & 3.76 & 11 & 0.9 & 6 \\
Participant 10 & Female & 86 & 6 & 6.98 & 3 & 0.5 & 0 \\
Participant 11 & Female & 331 & 7 & 2.11 & 3 & 0.4 & 0 \\
Participant 12 & Male & 475 & 12 & 2.53 & 6 & 0.5 & 1 \\
Participant 13 & Female & 127 & 3 & 2.36 & 3 & 1.0 & 1 \\
Participant 14 & Male & 524 & 21 & 4.01 & 15 & 0.7 & 10 \\
Participant 15 & Female & 337 & 10 & 2.97 & 8 & 0.8 & 4 \\
Participant 16 & Female & 161 & 2 & 1.24 & 2 & 1.0 & 1 \\
Participant 17 & Female & 155 & 3 & 1.94 & 1 & 0.3 & 1 \\
Participant 18 & Female & 425 & 9 & 2.12 & 7 & 0.8 & 5 \\
\hline
\end{tabular}

\section{Appendix B: Transcription conventions}

The annotation of the speech transcription is adapted from Du Bois (1991) and gestures transcription from McNeill (2005).

word: Elongation

word- Cut-off

/, //, $\quad$ Pauses (/ under $1 \mathrm{~ms}, / / /$ over $0.3 \mathrm{~ms}$ )

//I

[word] Gesture phase (from the first movement of the gesture to either a rest position or the next gesture starting). The gesture might have started in a previous utterance (no opening bracket shown) or might continue (no closing bracket shown).

word Gesture stroke 


\section{References}

Araújo Júnior, José Benivaldo. 2015. Las construcciones-SE impersonales y pasivas en español y en el PB: Reexaminando criterios de distinción. In Neide Maia González \&

María Teresa Celada (eds.), Interlocuciones entre el campo de los estudios del lenguaje y el de la formación de profesores. SIGNOS ELE, 9. http://p3.usal.edu.ar/index.php/ele/article/ view/3438, ISSN 1851-4863.

Azpiazu Torres, Susana. 2004. Reflexiones en torno al clítico se en español. ELUA. Estudios de Lingüística 18. 7-20.

Bielak, Jakub \& Mirostaw Pawlak. 2013. Applying Cognitive Grammar in the foreign language classroom: Teaching English tense and aspect. Berlin, Germany: Springer Science \& Business Media.

Boersma, Paul \& David Weenink. 2019. Praat: doing phonetics by computer [Computer program]. Version 6.0.54, http://www.praat.org/ (accessed 6 June 2019).

Brown, Amanda \& Jidong Chen. 2013. Construal of Manner in speech and gesture in Mandarin, English, and Japanese. Cognitive Linguistics 24. 605-631.

Brown, Amanda \& Marianne Gullberg. 2010. Changes in encoding of PATH of motion in a first language during acquisition of a second language. Cognitive Linguistics 21(2). 263-286.

Burgos, Manuel. No date. Revisión bibliográfica sobre las funciones y evolución del clítico se. Unpublished. https://studyres.es/doc/3082708/funciones-y-evolucio\%C3\%AC-n-de-se (accessed 22 August 2019).

Casasanto, Daniel \& Kyle Jasmin. 2012. The hands of time: Temporal gestures in English speakers. Cognitive Linguistics 2. 643-674.

Castro Castañeda, Alejandro. 2004a. Potencial pedagógico de la Gramática Cognitiva: Pautas para la elaboración de una gramática pedagógica de español/LE. redELE: Revista Electrónica de Didáctica ELE 6. https://www.educacion.gob.es/dctm/redele/Material-RedEle/Revista/ 2004_00/2004_redELE_0_06Castaneda.pdf (accessed 23 August 2019).

Castro Castañeda, Alejandro. 2004b. Gramática e imágenes. Ejemplos para el caso del español. Mosaico. Revista para la promoción y apoyo a la enseñanza del español 14. 7-11. Available at: http://www.sgci.mecd.es/be/media/pdfs/mosaico/Mosaico14.pdf.

Castro Castañeda, Alejandro \& Elisabeth Melguizo Moreno. 2006. Querían dormirlo, se ha dormido, está durmiendo. Gramática Cognitiva para la presentación de los usos del se en clase de ELE. Mosaico. Revista para la promoción y apoyo a la enseñanza del español 18. 13-20. Available at: https://cvc.cervantes.es/ensenanza/ese/programa_08/usos_se_ Castaneda_Melguizo_Mosaico18.pdf.

Cheikh-Khamis, Fátima. 2018. Reflexiones para la enseñanza de los verbos de cambio en ELE desde la perspectiva de la lingüística cognitiva. ResearchGate. http://researchgate.net (accessed 26 August 2019).

Chui, Kawai. 2011. Conceptual metaphors in gesture. Cognitive Linguistics 22. 437-458.

Cienki, Alan. 2015. Spoken language usage events. Language and Cognition 7(4). 499-514.

Cienki, Alan. 2017. From paralinguistic to variably linguistic. In Anne Barron, Yueguo Gu \& Gerard Steen (eds.), The Routledge handbook of pragmatics, 61-68. New York: Routledge.

Du Bois, John W. 1991. Transcription design principles for spoken discourse research. Pragmatics 1(1), 71-106.

Ellis, Nick C. \& Diane Larsen-Freeman. 2006. Language emergence: Implications for applied linguistics-Introduction to the special issue. Applied Linguistics 27. 558-589. 
Fauconnier, Gilles. 1994. Mental spaces: Aspects of meaning construction in natural language.

Cambridge, UK: Cambridge University Press.

Freleng, Friz. 1950. Canary Row [Film, animated cartoon]. New York: Tome Warner.

Gerwing, Jennifer \& Janet Bavelas. 2004. Linguistic influences on gesture’s form. Gesture 4(2). 157-195.

Gullberg, Marianne. 2009. Reconstructing verb meaning in a second language: How English speakers of L2 Dutch talk and gesture about placement. Annual Review of Cognitive Linguistics 7. 221-244.

Gullberg, Marianne. 2011. Thinking, speaking and gesturing about motion in more than one language. In Aneta Pavlenko (ed.), Thinking and speaking in two languages, 143-169. Bristol, UK: Multilingual Matters.

Holme, Randal. 2009. Cognitive linguistics and language teaching. New York: Palgrave Macmillan. Hudson, Natalie. 2011. Teacher gesture in a post-secondary English as a second language classroom: A sociocultural approach. Unpublished doctoral dissertation, Las Vegas: University of Nevada. https://digitalscholarship.unlv.edu/cgi/viewcontent.cgi?article= 2045\&context=thesesdissertations (accessed 24 April 2020).

Kemmer, Suzanne. 1993. The middle voice. Amsterdam: John Benjamins Publishing.

Kendon, Adam. 2004. Gesture: Visible action as utterance. Cambridge, UK: Cambridge University Press.

Kida, T. 2009. Does gesture aid discourse comprehension in second language?. In Steven G. McCafferty \& Gale Stam (eds.), Gesture: Second language acquisition and classroom research, 131-156. New York: Routledge.

Kok, Kasper I. \& Alan Cienki. 2016. Cognitive Grammar and gesture: Points of convergence, advances and challenges. Cognitive Linguistics 27. 67-100.

Ladewig, Silva H. 2011. Putting the cyclic gesture on a cognitive basis. CogniTextes. Revue de l'Association française de linguistique cognitive 6. https://doi.org/10.4000/cognitextes. 406.

Ladewig, Silva H. 2013. Recurrent gestures. In Cornelia Müller, Alan Cienki, Ellen Fricke, Silvia H. Ladewig, David McNeill \& Sedinha Tessendorf (eds.), Body-LanguageCommunication, 1558-1574. Berlin: De Gruyter.

Langacker, Ronald. 1987. Foundations of cognitive grammar: Theoretical prerequisites. California. Stanford University Press.

Langacker, Ronald. 1991. Cognitive grammar. In Flip Droste \& John Joseph (eds.), Linguistic theory and grammatical description, 275-306. Amsterdam: John Benjamins.

Langacker, Ronald. 2008. Cognitive grammar: A basic introduction. Oxford, M.A.: Oxford University Press.

Llopis-García, Reyes. 2010. Why cognitive grammar works in the L2 classroom: A case study of mood selection in Spanish. AlLA Review 23. 72-94.

Lopez-Ozieblo, Renia. 2018. Can gestures help clarify the meaning of the Spanish marker 'se'?. Lingua 208. 1-18.

Lopez-Ozieblo Renia. 2020. Proposing a revised functional classification of pragmatic gestures. Lingua, 102870. https://doi.org/10.1016/j.lingua.2020.102870, in press.

Lopez-Ozieblo Renia. Under review. Information theory might not be enough to explain gesturespeech unit frequencies. PloS One.

Lopez-Ozieblo, Renia \& David McNeill. 2017. Exchange on gesture-speech unity: What it is, where it came from. In Ruth Breckinridge Church, Martha W. Alibali \& Spencer Kelly (eds.), Why 
Gesture?: How the hands function in speaking, thinking and communicating, 103-125. Philadelphia, PA: John Benjamins Publishing Co.

Maldonado, Ricardo. 1999. Espacios mentales y la interpretación del se impersonal. El centro de lingüística hispánica y la lengua española, 205-227. México: Instituto de Investigaciones Filológicas.

Maldonado, Ricardo. 2000. Conceptual distance and transitivity increase. In Zygmunt Frajzyngier \& Traci S. Curl (eds.), Reflexives: forms and functions, 153-185. Amsterdam: John Benjamins.

Maldonado, Ricardo. 2008. Spanish middle syntax: A usage-based proposal for grammar teaching. In S. Sabine De Knop \& Teun De Rycker (eds.), Cognitive Approaches to Pedagogical Grammar, 155-196. Berlin: Mouton de Gruyter.

Maldonado, Ricardo. 2009. Middle as a basic voice system. Studies in Role and Reference Grammar. México: Instituto de Investigaciones Filológicas, UNAM. https:// ricardomaldonado.weebly.com/uploads/2/7/6/3/2763410/maldonado-rrg2007_final_ review.pdf (accessed 26 August 2019).

Maldonado, Ricardo. 2019. Una aproximación cognitiva al clítico se. Lingüística cognitiva y español LE/L2. In Iraide Ibarretxe-Antuñano, Teresa Cadierno \& Alejandro Castañeda Castro. Lingüística cognitiva y español LE/L2, 145-167. New York/Madrid: Routledge.

Matsumoto, Yumi \& Abby Mueller Dobs. 2017. Pedagogical gestures as interactional resources for teaching and learning tense and aspect in the ESL grammar classroom. Language Learning 67(1) 7-42.

McNeill, David. 1992. Hand and mind: What gestures reveal about thought. Chicago: University of Chicago Press.

McNeill, David. 2005. Gesture and thought. Chicago: University of Chicago Press.

McNeill, David. 2015. Why we gesture: The surprising role of hand movements in communication. Cambridge, UK: Cambridge University Press.

Melguizo Moreno, Elisabeth. 2006. El Sr. Se y su extraña familia. Una aproximación cognitiva a la presentación de los usos de se en clase de E/LE. Biblioteca 5. 1-159. https://www. educacionyfp.gob.es/dam/jcr:24bebcb6-886b-40e5-875e-2171e01e0519/2007-bv-07-14melguizo-pdf.pdf.

Mendikoetxea, Amaya. 1999. Construcciones con se: Medias, pasivas e impersonales. In Ignacio Bosque \& Violeta Demonte (eds.), Gramática Descriptiva de la Lengua Española, Ch. 26. Madrid: Espasa.

Montes Giraldo, José Joaquín. 2003. El “se” del español y sus problemas. Estudios Filológicos 38. 121-137.

Moreno Burgos, Juan. 2018. Semántica de los verbos de cambio. Great Britain: Amazon.

Müller, Cornelia. 2013. Gestural modes of representation as techniques of depiction. In Cornelia Müller, Alan Cienki, Ellen Fricke, Silvia H. Ladewig, David McNeill \&

Sedinha Tessendorf (eds.), Body-Language-Communication, 1687-1702. Berlin: De Gruyter.

Müller, Cornelia. 2004. Forms and uses of the palm up open hand: A case of a gesture family. In Cornelia Müller \& Roland Posner (eds.), The semantics and pragmatics of everyday gestures, 233-256. Berlin: Weidler.

Peris, Ernesto Martín. 2006. El pronombre se en la gramática de español para extranjeros: Entre el vocabulario y la gramática. In Elisenda Bernal \& Janet Ann DeCesaris (eds.), Palabra por palabra. Estudios ofrecidos a Paz Battaner, 161-178. Barcelona, Spain: Universitat Pompeu Fabra.

Real Academia Española. 2006. Diccionario esencial de la lengua española. Madrid, Spain: Espasa Calpe. 
Renau, Irene. 2015. Entre el léxico y la gramática: diccionarios de ELE para el aprendizaje de los verbos pronominales. Paper presented to the XXV Congreso Internacional de la ASELE. La enseñanza de ELE centrada en el alumno. Centro Virtual Cervantes, 2015.

Romero Trillo, Jesús. 2002. The pragmatic fossilization of discourse markers in non-native speakers of English. Journal of Pragmatics 34(6). 769-784.

Ruiz Campillo, José Plácido. 2007. Entrevista a José Plácido Ruiz Campillo: gramática cognitiva y ELE. MarcoELE Revista de Didáctica 5. https://marcoele.com/descargas/5/entrevista_jp. pdf (accessed 24 August 2019).

Saddour, Inès. 2017. A multimodal approach to investigating temporality expression in L2: What does gesture analysis reveal? International Review of Applied Linguistics in Language Teaching 55(3). 283-304.

Sánchez López, Cristina. 2002. Las construcciones con se. Madrid: Visor.

Sloetjes, Han. 2017. ELAN [Computer program]. Version 5.0.0.

Smotrova, Tetyana. 2014. Instructional functions of speech and gesture in the L2 classroom. Doctoral dissertation: Pennsylvania State University. https://etda.libraries.psu.edu/files/ final_submissions/10079 (accessed 24 April 2020).

Stam, Gale. 2015. Changes in thinking for speaking: A longitudinal case study. The Modern Language Journal 99. 83-99.

Stam, Gale. 2018. Gesture and speaking a second language. In Rosa Alonso Alonso (ed.), Speaking in a Second Language, 49-67. Amsterdam: John Benjamins.

Streeck, Jürgen. 2009. Gesturecraft. Amsterdam: John Benjamins.

Taibo, Marcelo. 2011. Las construcciones con se en una muestra del corpus de referencia del español actual (CREA). In Felix San Vicente (ed.), Portal de lingüística contrastiva españolitaliano. http://www.contrastiva.it/baul_contrastivo/dati/sanvicente/contrastiva/Gram\% C3\%A1tica\%20espa\%C3\%B1ola/Taibo,\%20construcciones\%20con\%20se.pdf (accessed 26 August 2019).

Taylor, John R. 2003. Cognitive grammar. Oxford, M.A.: Oxford University Press.

Torres González, Salomé, Alejandra Ros González, Santiago Rodríguez De La Calle, Yurena Pérez Torres, María Francisca, Celia Padrón Cifre, Inés Juez Calleja, Cortés Ortiz \& Lourdes Collado Romero. 2018. Un mapa de los vastos dominios del "señor se”. MarcoELE Revista de Didáctica 27. 1-35. https://marcoele.com/un-mapa-del-pronombre-se/. 